\title{
Heritability Estimates, Biometric and Allometric Growth Traits in F1 Progenies of the Nigerian Local Turkeys (Meleagris gallopova)
}

\author{
Nkiru Patience Uberu ${ }^{1}$, Ifemma Justina Emmanuel-Udeozor ${ }^{1}$, Eunice Amaka Akuru ${ }^{1,2^{*}}$, Augustine \\ Ogbonna Ani ${ }^{1}$, Chukwuemeka Eric Okuli ${ }^{1}$ and Chika Ethelbert Oyeagu ${ }^{3}$ \\ ${ }^{1}$ Department of Animal Science, University of Nigeria Nsukka, 410001, Nigeria \\ ${ }^{2}$ Department of Livestock and Pasture Science, University of Fort Hare, Alice 5700, South Africa \\ ${ }^{3}$ Department of Agriculture, Faculty of Applied Sciences, Cape Peninsula University of Technology, Wellington \\ Campus, Private Bag X8, Wellington 7654, Western Cape, South Africa \\ *Corresponding author: eunice.iloh@unn.edu.ng
}

Article History: $21-340 \quad$ Received: 22-Jun-21 Accepted: $13-J u l-21$
ABSTRA C T
The heritability estimates, biometric and allometric traits of the F1 progenies of Nigerian local turkeys were evaluated
from 0 to 8 weeks of age. Mature local turkeys ( $\mathrm{n}=21 ; 7$ males and 14 females) were used to generate 65 poults during
the study. Bi-weekly body weight $(\mathrm{BW})$ and linear body measurements (body length, BL; breast girth, BG; shank length,
SL; thigh length, TL; and keel length, KL) were taken for the 8 weeks. Results showed that sire significantly $(\mathrm{P}<0.05)$
affected the BW of progenies at 2,4 , and 8 weeks of age, and BL of the turkey progenies at 0,4 , and 8 weeks. There
were significant differences $(\mathrm{P}<0.05)$ in the BG at weeks 0 and 4 , KL at week 0 ; and KL length measurements at weeks
2 and 6 of age. The heritability $\left(\mathrm{h}^{2}\right)$ estimates for BW ranged from a low value $(0.14)$ at day-old, to a high value $(0.47)$
at 8 weeks. At weeks 6 and 8, the $\mathrm{h}^{2}$ values for BW, BL, and BG were all high, and positive, while $\mathrm{h}^{2}$ values for SL,
TL, and KL were low to moderate at week 8 , and at week 6 , the $\mathrm{h}^{2}$ values for SL and TL were negative. It was concluded
that the biometric traits of Nigerian indigenous turkeys showed high heritability values, hence, may respond to selection.
To this end, such potentials can be exploited in the genetic improvement of the Nigerian local turkeys.

Key words: Body weight, Body length, Breast girth, Estimates, Heritability, Growth, Local turkeys.

\section{INTRODUCTION}

Nigeria has 180 million poultry, out of which, $90 \%$ are indigenous birds (Desha et al. 2016; FAOSTAT 2017). The production of meat and eggs from poultry birds has the potential to meet human dietary protein requirements (Adeyonu et al. 2021). More so, the rearing of local turkeys, even at the family level, is still important in supplying the fast-growing human population with highquality protein and additional income (Gueye 2009; Bounds and Ziyemba 2018; Gunya et al. 2021). According to Alabi et al. (2006), rural women who keep poultry birds at the family level, generate almost $35 \%$ of their household income from this venture. This income is said to be about $25 \%$ of the Nigerian minimum wage and $50 \%$ of the per capita income of the nation. The importance of rural poultry to third-world countries such as Nigeria is typified in the way the birds are produced and used on a large scale. Rural poultry is the most vital resource in rural Africa,
Asia, and Latin America. This is because these birds are small-sized, easy to manage, have a short period of gestation, highly prolific, can forage for themselves, and have a natural desire to stay around the house (Dessie et al. 2011; Padhr 2016).

Sadly, despite the higher benefits of the turkey bird over the chicken, its production is still hampered in developing countries (Perez-Lara et al. 2013). Yakubu et al. (2013) noted that apart from their high capacity to tolerate heat and survive under arid conditions, turkeys can forage over long distances, and produce meat with improved quality. The Nigerian indigenous turkeys just like the local chickens, have low body weight, slow growth rate, and lay small-sized eggs, due to exposure to lowquality feed regimens (Udoh et al. 2012; Ngu et al. 2014) These local turkeys can survive the disease and harsh environmental conditions that are peculiar to the rural communities due to their resilient nature (Ilori et al. 2017; Manyelo et al. 2020). Arnould and Leterrier (2007)

Cite This Article as: Uberu NP, Emmanuel-Udeozor IJ, Akuru EA, Ani AO, Okuli CE and Oyeagu CE, 2022. Heritability estimates, biometric and allometric growth traits in F1 progenies of the Nigerian local turkeys (Meleagris gallopova). International Journal of Veterinary Science 11(1): 68-73. https://doi.org/10.47278/journal.ijvs/2021.077 
concluded that genetic improvement of locally produced birds, including turkeys, can help to alleviate the problem of animal protein shortage especially in a rural area, and will also go a long way in boosting the Nigerian dwindling economy. Selection has been found to improve the growth rate and body composition traits in indigenous poultry (Ankra-Badu et al. 2010). Thus, the Nigerian local turkey can be improved by obtaining information on heritability, and the genetic correlation of key growth and egg traits, in a bid to enhance the accuracy of predicting response to selection, thereby leading to improved growth and egglaying performance of the local turkey.

Heritability, a vital genetic parameter, refers to the portion of the additive variance that can be attributed to genetic factors, i.e., that which will be transferred from parents to their offspring (Visscher et al. 2008; Awany and Chimusa 2021). Information regarding heritability estimates $\left(\mathrm{h}^{2}\right)$ is an important tool in animal breeding that is used to predict probable response to or progress from selection (Visscher et al. 2008). Production traits are interrelated; hence, considerations of such relationships are pertinent in the choice of appropriate methods of selection. More so, breeding programs for meat-type birds involves selecting for body weight (BW) and body conformation, such as the yield of breast portion (Ogah 2011; Hartcher and Lum 2020). Luiting and Uriff (1991) reported that BW traits were influenced by genetics and common or maternal environmental effects. The reports of Arthur and Abplanalp (1992) revealed that the BW traits of birds at various ages had an average heritability of 0.41. Busye et al. (2001) also made a similar observation. The author recorded an $h^{2}$ estimate of 0.23 to 0.71 , for BW traits at different ages. Since, the common environmental effect largely influences the $\mathrm{h}^{2}$ estimates for $\mathrm{BW}$ traits, particularly when the animals are young, neglect of this effect would lead to an overestimated heritability estimate at early ages. In the work of Nestor et al. (1967), a selected population of turkey birds was found to have un-weighted averages of $\mathrm{h}^{2}$ estimates of $\mathrm{BW}$ in the range of $0.40,0.42,0.43$, and 0.36 at 0 to 8,9 to 16,17 to 24 , and over 24 weeks, respectively. In the study of Aslam et al. (2011), a low $\mathrm{h}^{2}$ of 0.0 and 0.12 was recorded for BW at 1 and 17 days.

This study, therefore, was conducted to evaluate the heritability estimates and the allometric and biometric growth traits among the half-sib progeny of Nigerian local turkeys.

\section{MATERIALS AND METHODS}

\section{Experimental Location and Duration}

The experiment which lasted for 8 weeks was carried out in 2018 at the turkey section of the Department of Animal Science Poultry Unit, University of Nigeria, Nsukka. The ethical protocols obtained for the study were as permitted for the use of animals in biomedical research by the Ethical Research Committee of the University of Nigeria, Nsukka (2006).

\section{Experimental Birds and Management}

The foundation stocks were 21 mature Nigerian local turkeys, comprising of seven sires and fourteen dams. The experimental birds consisted of 65 progenies, produced from mating involving three different strains of local female turkeys (white, black, and bronze). The foundation stock was grouped into seven, each group containing one sire and two dams in a separate pen and was allowed to breed naturally. Fertile eggs were collected daily with egg crates and stored at room temperature of $21-24^{\circ} \mathrm{C}$ and relative humidity of $80 \%$. Eggs from hens in each family were identified with a marker. Fertile eggs were taken to the hatchery every 10 days for hatching in batches of 30 eggs per set. The egg collection lasted for 2 months. Soon after hatching, colored markers, rings, and cloths were used to identify chicks from each sire or tom. The markers were regularly checked and replaced as often as possible to prevent the chicks belonging to the various groups from mixing up. Each batch of turkey poults was brooded for six weeks. Adequate brooding house and brooding conditions were also provided to the chicks. Water and feed were given to them ad libitum. Also, necessary vaccinations and medications were administered in addition to proper management practices.

\section{Data Collection}

The parameters that were evaluated during the study were as follows:

Biometric traits: This includes body weight (BW) and body weight gain. The BW records were measured in grams using a digital weighing scale, and this was done on a bi-weekly basis for eight weeks.

Allometric traits: The allometric traits evaluated include body length, shank length, thigh length, keel length, and breast girth. All these body conformation traits were measured in centimeters with the aid of a measuring tape.

\section{Statistical Analysis}

The experiment was carried out using a completely randomized design, and Nested or Hierarchical design. The hierarchical ANOVA model (dams nested within sires) is given as:

$\mathrm{Y}_{\mathrm{ijk}}=\mu+\mathrm{a}_{\mathrm{i}}+\mathrm{b}_{\mathrm{ij}}+\mathrm{e}_{\mathrm{ijk}}$

$Y_{i j k}=$ an observation of the kth progeny of the jth dam mated to the ith sire.

$\mu \quad=$ the mean, i.e., the expected value of the observations, $j$. $\mu+a_{i} \quad=$ the effect of the ith sire or expected value of the progeny of ith sire.

$\mu+a_{i}+b_{i j}=$ the effect of the $j$ th dam mated to the ith sire or expected value of the progeny of the jth dam mated to ith sire $\mathrm{e}_{\mathrm{ijk}}=$ the deviation (error) of the observed value of the kth progeny (of the jth dam mated to the ith sire) from the expected value of the progeny of the jth dam. In other words, the random error due to the uncontrollable environmental and genetic deviations attributed to the individual.

\section{RESULTS}

Table 1 shows the effect of sire on progenies' average body weight (ABW) of the Nigerian local turkey at two weeks intervals. The body weights of the sire's progeny at weeks $0,2,4,6$ and 8 ranged from $38.89 \pm 1.11$ to $48.00 \pm 3.74,108.33 \pm 7.03$ to $154.00 \pm 4.00,248.33 \pm 17.59$ to $292.00 \pm 14.97, \quad 368.89 \pm 29.65$ to $435.00 \pm 54.61$ and $612.00 \pm 36.66$ to $797.50 \pm 54.57$, respectively. There BW of the progenies of the 7 turkey sires differed significantly $(\mathrm{P}<0.05)$ only at 2 weeks of age. Although the progenies from sire A, B, C, F and $\mathrm{G}$ were comparable $(\mathrm{P}>0.05)$ in 
Int J Vet Sci, 2022, 11(1): 68-73

Table 1: Sire effect on average body weight (g) of local turkey progenies at two weekly intervals

Parameters/

Sire number

Sire A

Sire B

Sire C

Sire D

Sire E

Sire F

Sire G

\begin{tabular}{c}
\hline BWO \\
$38.89 \pm 1.11$ \\
$48.00 \pm 3.74$ \\
$48.00 \pm 3.74$ \\
$42.00 \pm 3.39$ \\
$44.17 \pm 3.75$ \\
$43.75 \pm 1.83$ \\
$45.63 \pm 1.75$
\end{tabular}

BW2
$151.11 \pm 0.76^{\mathrm{a}}$
$154.00 \pm 4.00^{\mathrm{a}}$
$140.00 \pm 9.86^{\mathrm{a}}$
$98.00 \pm 18.54^{\mathrm{b}}$
$108.33 \pm 7.03^{\mathrm{b}}$
$138.75 \pm 1.41^{\mathrm{a}}$
$140.00 \pm 7.32^{\mathrm{a}}$

BW4

Age (weeks)

Mean \pm SD having different subscripts in the same column are significantly different $(\mathrm{P}<0.05)$. BW: Body weight.

$280.00 \pm 5.28 \quad 368.89 \pm 29.65 \quad 704.44 \pm 0.77$

$292.00 \pm 14.97 \quad 410.00 \pm 31.94$

$670.00 \pm 75.50$

$\begin{array}{lll}251.11 \pm 13.06 & 397.50 \pm 30.10 & 797.50 \pm 54.57\end{array}$

$273.33 \pm 6.67 \quad 386.67 \pm 35.28 \quad 613.33 \pm 96.15$

$248.33 \pm 17.59 \quad 386.00 \pm 34.87 \quad 612.00 \pm 36.66$

$250.00 \pm 11.34 \quad 374.29 \pm 28.52 \quad 666.67 \pm 83.69$

$\begin{array}{lll}250.00 \pm 11.34 & 374.29 \pm 28.52 & 666.67 \pm 83.69 \\ 265.00 \pm 13.50 & 435.00 \pm 54.61 & 792.50 \pm 43.74\end{array}$

Table 2: Sire effect on average body length $(\mathrm{cm})$ of local turkey progenies at two weekly intervals

\begin{tabular}{llllll}
\hline Parameters/ & \multicolumn{5}{c}{ Age (weeks) } \\
\cline { 2 - 6 } Sire number & BLO & BL2 & BL4 & BL6 & BL8 \\
\hline Sire A & $13.57 \pm 0.38^{\mathrm{a}}$ & $21.06 \pm 0.42^{\mathrm{a}}$ & $23.06 \pm 2.53^{\mathrm{b}}$ & $29.03 \pm 2.70^{\mathrm{a}}$ & $35.00 \pm 0.33^{\mathrm{b}}$ \\
Sire B & $12.74 \pm 0.51^{\mathrm{ab}}$ & $21.10 \pm 0.43^{\mathrm{a}}$ & $28.10 \pm 0.71^{\mathrm{a}}$ & $32.85 \pm 1.20^{\mathrm{a}}$ & $37.60 \pm 1.68^{\mathrm{a}}$ \\
Sire C & $13.78 \pm 0.26^{\mathrm{a}}$ & $20.49 \pm 0.38^{\mathrm{a}}$ & $25.94 \pm 0.93^{\mathrm{ab}}$ & $31.92 \pm 0.88^{\mathrm{a}}$ & $37.90 \pm 0.82^{\mathrm{a}}$ \\
Sire D & $12.42 \pm 0.45^{\mathrm{b}}$ & $20.08 \pm 0.57^{\mathrm{ab}}$ & $27.17 \pm 0.44^{\mathrm{a}}$ & $18.59 \pm 0.72^{\mathrm{b}}$ & $35.00 \pm 1.00^{\mathrm{b}}$ \\
Sire E & $12.70 \pm 0.33^{\mathrm{ab}}$ & $18.88 \pm 0.33^{\mathrm{b}}$ & $25.12 \pm 0.83^{\mathrm{ab}}$ & $30.21 \pm 0.77^{\mathrm{a}}$ & $35.30 \pm 0.70^{\mathrm{b}}$ \\
Sire F & $12.99 \pm 0.15^{\mathrm{ab}}$ & $20.44 \pm 0.56^{\mathrm{a}}$ & $25.64 \pm 0.60^{\mathrm{ab}}$ & $31.24 \pm 1.10^{\mathrm{a}}$ & $36.83 \pm 1.60^{\mathrm{b}}$ \\
Sire G & $12.96 \pm 0.51^{\mathrm{ab}}$ & $20.67 \pm 0.37^{\mathrm{a}}$ & $26.54 \pm 0.32^{\mathrm{ab}}$ & $32.59 \pm 0.59^{\mathrm{a}}$ & $38.63 \pm 0.85^{\mathrm{a}}$
\end{tabular}

Mean \pm SD having different subscripts in the same columns are significantly different $(\mathrm{P}<0.05)$. BL: Body length.

Table 3: Sire effect on breast girth $(\mathrm{cm})$ of local turkey progenies at two weekly intervals

\begin{tabular}{lccccc} 
Parameters/ & \multicolumn{5}{c}{ Age (Weeks) } \\
\cline { 2 - 5 } Sire number & BRGO & BRG2 & BRG4 & BRG6 & BRG8 \\
\hline Sire A & $2.70 \pm 0.07^{\mathrm{a}}$ & $5.19 \pm 0.24$ & $6.91 \pm 0.31^{\mathrm{a}}$ & $7.94 \pm 0.29$ & $10.78 \pm 0.49$ \\
Sire B & $2.68 \pm 0.07^{\mathrm{a}}$ & $5.00 \pm 0.22$ & $7.20 \pm 0.41^{\mathrm{a}}$ & $9.40 \pm 0.40$ & $10.50 \pm 0.50$ \\
Sire C & $2.74 \pm 0.06^{\mathrm{a}}$ & $5.11 \pm 0.27$ & $6.78 \pm 0.39^{\mathrm{a}}$ & $8.40 \pm 0.40$ & $10.25 \pm 0.46$ \\
Sire D & $2.38 \pm 0.05^{\mathrm{b}}$ & $5.34 \pm 0.45$ & $5.17 \pm 2.59^{\mathrm{b}}$ & $8.00 \pm 0.29$ & $10.17 \pm 1.20$ \\
Sire E & $2.63 \pm 0.08^{\mathrm{a}}$ & $4.40 \pm 0.13$ & $6.95 \pm 0.47^{\mathrm{a}}$ & $7.64 \pm 0.30$ & $10.00 \pm 0.35$ \\
Sire F & $2.63 \pm 0.06^{\mathrm{a}}$ & $5.25 \pm 0.25$ & $6.69 \pm 0.35^{\mathrm{a}}$ & $7.79 \pm 0.34$ & $11.17 \pm 0.33$ \\
Sire G & $2.79 \pm 0.08^{\mathrm{a}}$ & $5.06 \pm 0.19$ & $7.38 \pm 0.23^{\mathrm{a}}$ & $8.25 \pm 0.34$ & $11.25 \pm 0.42$
\end{tabular}

Mean \pm SD having different subscripts in the same column are significantly different $(\mathrm{P}<0.05)$. BRG: Breast girth.

Table 4: Sire effect on shank length $(\mathrm{cm})$ of local turkey progenies at two weekly intervals

\begin{tabular}{lccccc} 
Parameters/ & \multicolumn{5}{c}{ Age (weeks) } \\
\cline { 2 - 6 } Sire number & SLO & SL2 & SL4 & SL6 & SL8 \\
\hline Sire A & $2.37 \pm 0.06$ & $3.49 \pm 0.07$ & $4.70 \pm 0.15$ & $5.87 \pm 0.13$ & $7.17 \pm 0.19$ \\
Sire B & $2.40 \pm 0.05$ & $3.70 \pm 0.09$ & $4.90 \pm 0.23$ & $5.94 \pm 0.18$ & $7.00 \pm 0.71$ \\
Sire C & $4.84 \pm 2.45$ & $3.36 \pm 0.10$ & $4.46 \pm 0.15$ & $5.53 \pm 0.28$ & $7.62 \pm 0.28$ \\
Sire D & $2.36 \pm 0.06$ & $3.66 \pm 0.16$ & $4.73 \pm 0.03$ & $5.80 \pm 0.23$ & $7.17 \pm 0.44$ \\
Sire E & $2.28 \pm 0.04$ & $3.45 \pm 0.06$ & $4.45 \pm 0.12$ & $5.64 \pm 0.38$ & $6.50 \pm 0.16$ \\
Sire F & $2.35 \pm 0.03$ & $3.38 \pm 0.08$ & $4.55 \pm 0.03$ & $5.43 \pm 0.28$ & $7.43 \pm 0.40$ \\
Sire G & $2.44 \pm 0.05$ & $3.64 \pm 0.13$ & $4.66 \pm 0.09$ & $5.64 \pm 0.27$ & $7.50 \pm 0.23$ \\
\hline
\end{tabular}

Values (Mean $\pm \mathrm{SD})$ in the same column differ non-significantly $(\mathrm{P}>0.05)$. SL: Shank length.

their BW, the values were statistically $(\mathrm{P}<0.05)$ higher than the $\mathrm{BW}$ of the progenies of sire $\mathrm{D}$ and $\mathrm{E}$. The $\mathrm{BW}$ of the progenies of the sires at weeks $0,4,6$, and 8 were found to be statistically $(\mathrm{P}>0.05)$ the same.

\section{Body Length (cm)}

There were significant $(\mathrm{P}<0.05)$ differences in average body length (ABL) traits of the Nigerian local turkey progeny at weeks $2,4,6$, and 8 as shown in Table 2 . The mean body lengths of the turkey sire's progeny ranged from $12.42 \pm 0.45$ at week 0 to $38.63 \pm 0.85$ at week 8 .

\section{Breast Girth}

The results on the effect of sire on the average breast girth of sires' progeny of Nigerian indigenous local turkeys from weeks 1 to 8 are shown in Table 3 . The mean breast girth value of the sire progenies ranged from $2.38 \pm 0.05$ for week one, to $11.25 \pm 0.42$ at week 8 of age. There were significant differences $(\mathrm{P}<0.05)$ among the breast girth trait of the local turkey progeny at weeks 0 and 4 . The mean breast girth value of sire A, B, C, E, F, and G was the same $(\mathrm{P}>0.05)$ and were significantly $(\mathrm{P}<0.05)$ higher than those of sire $\mathrm{D}$. The mean breast girth value of the progenies at week zero ranged from $2.38 \pm 0.05$ to $2.79 \pm 0.08$.

\section{Shank Length}

The effects of sire on the average thigh and shank lengths of the Nigerian indigenous local turkey progenies from weeks 1 to 8 are shown in Table 4 and 5. There were no significant $(\mathrm{P}<0.05)$ differences among the thigh length and shank length of the turkey sire progeny. The mean values for thigh length ranged from $3.40 \pm 0.10$ at week one to $12.16 \pm 0.37$ at week 8 , and $0.28 \pm 0.04$ at week 0 , to $7.62 \pm 0.28$ at week 8 for the shank length.

\section{Keel Length}

The results in Table 6 showed that there were significant $(\mathrm{P}<0.05)$ differences at 0,4 , and 8 weeks of age 
Int J Vet Sci, 2022, 11(1): 68-73

Table 5: Sire effect on thigh length $(\mathrm{cm})$ of local turkey progenies at two weekly intervals

\begin{tabular}{llllll}
\hline Parameters & \multicolumn{5}{c}{ Age (weeks) } \\
\cline { 2 - 6 } Sire number & THLO & THL2 & THL4 & THL6 & THL8 \\
\hline Sire A & $3.78 \pm 0.09$ & $3.46 \pm 0.05$ & $7.99 \pm 0.20$ & $8.58 \pm 0.33$ & $11.00 \pm 0.17$ \\
Sire B & $3.46 \pm 0.05$ & $5.72 \pm 0.24$ & $8.56 \pm 0.31$ & $9.30 \pm 0.20$ & $11.13 \pm 0.66$ \\
Sire C & $3.68 \pm 0.09$ & $5.92 \pm 0.20$ & $7.51 \pm 0.24$ & $9.21 \pm 0.34$ & $11.67 \pm 0.63$ \\
Sire D & $3.40 \pm 0.10$ & $5.92 \pm 0.32$ & $5.77 \pm 2.63$ & $9.67 \pm 0.33$ & $10.83 \pm 0.60$ \\
Sire E & $3.53 \pm 0.14$ & $5.62 \pm 0.10$ & $7.90 \pm 0.31$ & $9.12 \pm 0.38$ & $10.74 \pm 0.27$ \\
Sire F & $3.54 \pm 0.09$ & $6.09 \pm 0.18$ & $7.88 \pm 0.16$ & $9.06 \pm 0.36$ & $11.25 \pm 0.70$ \\
Sire G & $3.50 \pm 0.09$ & $5.60 \pm 0.16$ & $8.00 \pm 0.22$ & $8.93 \pm 0.45$ & $12.16 \pm 0.37$
\end{tabular}

Values $(M e a n+S D)$ in the same column differ non-significantly $(\mathrm{P}>0.05)$. THL: Thigh length.

Table 6: Sire effect on keel length $(\mathrm{cm})$ of local turkey progenies at two weekly intervals

\begin{tabular}{llllll}
\hline Parameters & \multicolumn{5}{c}{ Age (weeks) } \\
\cline { 2 - 5 } Sire number & KLO & KL2 & KL4 & KL6 & KL8 \\
\hline Sire A & $2.37 \pm 0.04^{\mathrm{a}}$ & $4.49 \pm 0.18$ & $5.77 \pm 0.18^{\mathrm{ab}}$ & $5.94 \pm 0.29$ & $6.76 \pm 0.15^{\mathrm{b}}$ \\
Sire B & $2.38 \pm 0.04^{\mathrm{a}}$ & $5.12 \pm 0.12$ & $6.26 \pm 0.41^{\mathrm{a}}$ & $6.80 \pm 0.20$ & $7.43 \pm 0.42^{\mathrm{ab}}$ \\
Sire C & $2.39 \pm 0.04^{\mathrm{a}}$ & $4.66 \pm 0.13$ & $5.79 \pm 0.25^{\mathrm{ab}}$ & $6.65 \pm 0.23$ & $7.97 \pm 0.41^{\mathrm{a}}$ \\
Sire D & $2.12 \pm 0.06^{\mathrm{b}}$ & $4.58 \pm 0.17$ & $5.33 \pm 0.17^{\mathrm{b}}$ & $6.10 \pm 0.31$ & $6.50 \pm 0.29^{\mathrm{b}}$ \\
Sire E & $2.25 \pm 0.99^{\mathrm{ab}}$ & $4.12 \pm 0.08$ & $5.12 \pm 0.18^{\mathrm{b}}$ & $6.54 \pm 0.20$ & $7.10 \pm 0.25^{\mathrm{ab}}$ \\
Sire F & $2.41 \pm 0.05^{\mathrm{a}}$ & $4.50 \pm 0.21$ & $5.25 \pm 0.10^{\mathrm{b}}$ & $6.14 \pm 0.14$ & $7.25 \pm 0.56^{\mathrm{ab}}$ \\
Sire G & $2.34 \pm 0.06^{\mathrm{a}}$ & $4.55 \pm 0.19$ & $5.54 \pm 0.24^{\mathrm{ab}}$ & $6.30 \pm 0.24$ & $8.12 \pm 0.23^{\mathrm{a}}$ \\
\hline
\end{tabular}

Mean \pm SD having different subscripts in the same column are significantly different $(\mathrm{P}<0.05)$. KL: Keel length.

Table 7: Heritability estimates of biometric and allometric traits of local turkey progenies

\begin{tabular}{llllll}
\hline & \multicolumn{5}{c}{ Age (weeks) } \\
\cline { 2 - 6 } & $\mathrm{O}$ & 2 & 4 & 6 & 8 \\
\hline Barameters & $0.29^{\mathrm{ab}}$ & $0.16^{\mathrm{b}}$ & $0.14^{\mathrm{b}}$ & $0.41^{\mathrm{a}}$ & $0.47^{\mathrm{a}}$ \\
Body length $(\mathrm{g})$ & $0.22^{\mathrm{b}}$ & $0.69^{\mathrm{a}}$ & $0.15^{\mathrm{b}}$ & $0.05^{\mathrm{c}}$ & $0.70^{\mathrm{a}}$ \\
Breast girth $(\mathrm{cm})$ & $0.80^{\mathrm{a}}$ & $0.10^{\mathrm{b}}$ & $0.01^{\mathrm{c}}$ & $0.62^{\mathrm{a}}$ & $0.85^{\mathrm{a}}$ \\
Shank length $(\mathrm{cm})$ & $-0.14^{\mathrm{c}}$ & $0.44^{\mathrm{a}}$ & $0.16^{\mathrm{b}}$ & $-0.29^{\mathrm{c}}$ & $0.19^{\mathrm{b}}$ \\
Thigh length (cm) & $0.42^{\mathrm{a}}$ & $0.03^{\mathrm{c}}$ & $0.51^{\mathrm{a}}$ & $-0.21^{\mathrm{d}}$ & $0.23^{\mathrm{b}}$ \\
Keel length $(\mathrm{cm})$ & $0.86^{\mathrm{a}}$ & $0.60^{\mathrm{a}}$ & $0.70^{\mathrm{a}}$ & $0.34^{\mathrm{b}}$ & $0.14^{\mathrm{c}}$ \\
\hline
\end{tabular}

Mean+SD having different subscripts in the same column are significantly different $(\mathrm{P}<0.05)$.

for the keel length. The keel length value of the local turkey progeny was within the range of $2.12 \pm 0.06$ at week 0 to $8.13 \pm 0.23$ at week 8 . In week 0 , the mean keel length values of turkey poults from sire A, B, C, F, and G were similar to those of sire $\mathrm{E}$ and were higher $(\mathrm{P}<0.05)$ than the progenies of sire D. In week 4, the keel length value of sire D, E, and F were similar to those of sire A, C, and G. The progenies of sire B has the highest mean value for keel length. In week 8 , the mean keel length value of sire $C$ and $G$ progenies were similar to those of sire B, E, and F. The progenies of sire $\mathrm{A}$ and $\mathrm{D}$ have the least mean value.

\section{Heritability Estimates}

Table 7 shows the heritability $\left(\mathrm{h}^{2}\right)$ of the linear body parameters evaluated in the present study. A very high heritability value was obtained for breast girth (0.8), keel length (0.86) and thigh length (0.42) at day-old. Heritability of body weight and body length was moderate at 0 weeks i.e., day-old with the estimated values of 0.29 and 0.22 , respectively. Heritability of all other parameters ranged from moderate to high at week 0 with the heritability estimate ranging from 0.22 for body length to 0.85 for keel length. Moreover, estimates of heritability for body weight, body length, and breast girth were high at week 8 with the estimated values of $0.47,0.70$, and 0.83 , respectively. Conversely, the heritability estimates for shank length, thigh length, and keel length decreased to low heritability with an estimated value of 0.19 for shank length (low), 0.22 (moderate) for thigh length and 0.13 (low) for the keel. There were no specific trends in the estimate from week 0 to week 8 .

\section{DISCUSSION}

\section{Linear Body Measurements}

The increasing trend from 0 to 8 weeks obtained in this study for body weight and other linear body measurements as the bird advanced in age is supportive of the previous reports of Adeyinka and Mohummed (2006). This suggests that growth and physiological development are determined mainly by age. The mean body weight, shank length, and thigh length reported in this study at week 8 were lower than the value recorded in the study of Heinrichs et al. (1992). They reported a mean value of $1630 \mathrm{~g}$ for body weight, $11.6 \mathrm{~cm}$ for shank length, and $9.3 \mathrm{~cm}$ for keel length. The difference between their result and our values could either be due to the use of different strains of turkeys or in part due to differences in experimental techniques and management. The significant effect of sires obtained in some linear body measurements and bodyweight of the turkey poult at various ages implies that there are considerable genetic contributions of sires to these traits. Therefore, an appropriate selection program that will ensure the use of proven sire in the poultry combined with good mating systems would yield good results.

\section{Heritability Estimates}

According to Abplanalp and Kosin (1995), the majority of the $\mathrm{h}^{2}$ estimates of BW of turkey range from a low value of 0.16 to a high value of 0.62 , with the majority being from 0.35 to 0.50 . The heritability estimates of body weight at week $4(0.14)$ which we obtained was similar to those reported by Aslam et al. (2011). According to Tullett 
and Burton (1982), there is a $97 \%$ variation in the weight of chicks at hatching owing to the weight of the fresh eggs and the weight lost from the eggs during incubation.

Besides, $70 \%$ of the weight of chicks is attributed to the weight of the eggs (Iqbal et al. 2017). Hence, the results we obtained indicate that body weight at day-old was not heritable, and that the common environmental effect has a huge influence on the estimate of heritability for bodyweight traits, particularly at younger ages. The low heritability at younger ages also indicates less genetic variability, relative to phenotypic variability among the poults. The implication of this is that the selection of traits of interest at younger ages may not result in any appreciable improvement. Therefore, cross-breeding is the first option for the improvement of lowly heritable traits. It will bring about heterosis and gene complimentary in the crossbred individuals. Subsequently, such gain can be consolidated by selection. The moderate to low heritability estimates observed for most of the traits at weeks 0 to 4 could be due to non-additive genetic effects such as dominance and epistasis which are not transferable from parents to their offspring. As from weeks 6 to 8, there was an increase in the observed heritability especially for body weight, breast girth, and body length.

The high heritability estimates of the parameters evaluated in this study are an indication that variability due to additive gene action is probably higher than the nonaddictive component, and genetic progress can be made through selection. This implies that a larger proportion of the superiority of the parents will be retained in the offspring. In comparison to other studies, heritability estimates of this study did not follow a specific trend but were slightly higher than the value obtained by Aslam et al. (2011). The value of heritability estimates of body weight obtained in this study at week $8(0.47)$ was in line with that reported by Nestor et al. (1967). Since the highest heritability estimates were obtained at weeks 6 and 8 for most of the traits evaluated, selection of local turkey breeders can be carried out at these ages to ensure genetic improvement thereafter.

\section{Conclusion}

The findings of our study showed that body weight, body length, and breast girth at 8 weeks could be used as traits for the selection of parents of the next generation, while thigh length and keel length at 4 weeks were the best predictors of genetic improvement through selection. Although the heritability of keel length at week 0 was very high, it is not recommended to carry out the selection at this age, because heritability estimates at earlier ages are usually influenced by maternal and environmental effects. From our results, it was evident that the Nigerian local turkeys vary significantly in their allometric and biometric (growth) traits. In addition, individual differences between sires in both the allometric and the biometric traits suggest the importance of using proven sires in the selective breeding of productive turkey birds. The age differences in the body weight and linear body measurements observed in the study also confirm the fact, that age is the main nongenetic factor that influences growth and physiological development. Given this, evaluations of allometric and biometric growth traits would be most acceptable in growing turkeys between 2 and 8 weeks of age. The biometric traits of Nigerian local turkey also showed high heritability both at the day-old and particularly, at week 8 . Such potentials can be utilized in such a way that the local turkeys can be genetically improved, via selection at the 8th week of age.

\section{Author's Contribution}

UNP: Edited the manuscript. EUIJ: Edited the manuscript. AEA: Literature search, edited the manuscript. AOA: Designed and supervised the study, wrote the original draft. OCE: Conducted the experiment, collected the data. OCE: Edited the manuscript.

\section{Acknowledgements}

The authors wish to acknowledge the Department of Animal Science, the University of Nigeria Nsukka for providing the facilities used for this study.

\section{REFERENCES}

Adeyinka IA and Mohummed ID, 2006. Relationship of live weight and linear body measurements in two breeds of goat of Northern Nigeria. Journal of Animal and Veterinary Advances 5: 891-893.

Adeyonu AG, Okunola A, Alao ME, Oyawoye EO and Okonkwo CE, 2021. An assessment of broiler value chain in Nigeria. Open Agriculture 6: 296-307. https://doi.org/10.1515/opag2020-0168

Alabi RA, Esobhawan AO and Aruna MB, 2006. Econometric determination of contribution of family poultry to women's income in Niger-delta, Nigeria. Journal of Central European Agriculture 7: 753-760.

Ankra-Badu GA, Le Bihan-Duval E, Mignon-Grasteau S and Pitel F, 2010. Mapping QTL for growth and shank traits in chickens divergently selected for high or low body weight. Animal Genetics 41: 400-405. https://doi.org/10.1111/j. 1365-2052.2009.02017.x

Arnould C and Leterrier C, 2007. Welfare of chickens reared for meat production. Productions Animals 20: 41-45.

Arthur JA and Abplanalp H, 1992. Linear estimates of heritability and genetic correlation for egg production, body weight, conformation and egg weight of turkeys. Poultry Science 54: 11-23.

Aslam ML, Bastiaansen JWM, Crooijmans RPMA, Ducro BJ, Vereijken A and Groenen MAM, 2011. Genetic variances, heritabilities and maternal effects on body weight, breast meat yield, meat quality traits and the shape of the growth curve in turkey birds. BMC Genetics 12: 14-23. https://doi.org/10.1186/1471-2156-12-14

Awany D and Chimusa ER, 2021. Heritability jointly explained by host genotype and microbiome: will improve traits prediction? Briefings in Bioinformatics 22: bbaa175. https://doi.org/ 10.1093/bib/bbaa175

Bounds M and Zinyamba O, 2018. Poultry farming: Lessening poverty in rural areas. South African Journal of Agricultural Extension 46: 59-70. https://dx.doi.org/10.17159/2413322/2018/v46n1a436

Busye J, Janssens GP and Decuypre E, 2001. The effects of dietary L-carnitine supplementation on the performance, organ weights and circulating hormones and metabolite concentrations of broiler chickens reared under a normal or low temperature. British Poultry Science 42: 230-241. https://doi.org/10.1080/00071660120048492

Desha NH, Bhuiyan MSA, Islam F and Bhuiyam AKFH, 2016. Non-genetic factors affecting growth performance of indigenous chicken in rural villages. Journal of Tropical Resources and Sustainable Science 4: 122-127. 
Dessie T, Taye T, Dana N, Ayalew W and Hanotte O, 2011. Current state of knowledge on phenotypic characteristics of indigenous chickens in the tropics. World's Poultry Science Journal 67: 507-516. https://doi.org/10.1017/S00439339110 $\underline{00559}$

FAOSTAT, 2017. Food and Agricultural Organization of the United Nations, 2017. Available from http://www.fao.org/ statistics/en/

Gueye EF, 2009. The role of networks in information dissemination to family poultry farmers. World's Poultry Science Journal 65: 115-124. https://doi.org/10.1017/ $\underline{\text { S0043933909000099 }}$

Gunya B, Muchenje V, Gxasheka M, Tyasi LT and Masika PJ, 2020. Management practices and contribution of village chickens to livelihoods of communal farmers: The case of Centane and Mount Frere in Eastern Cape, South Africa. Biodiversitas Journal of Biological Diversity 21: 1345-1351. https://doi.org/10.13057/biodiv/dz10410

Hartcher KM and Lum HK, 2020. Genetic selection of broilers and welfare consequences: a review. World's Poultry Science Journal 76: 154-167. https://doi.org/10.1080/ 00439339.2019 .1680025

Heinrichs AJ, Rogers GW and Cooper JB, 1992. Predicting body weight and wither height in Holstein heifers using body measurements. Journal of Dairy Science 75: 3576-3581. https://doi.org/10.3168/jds.S0022-0302(92)78134-X

Ilori BM, Oguntade DO, Akano K, Drusaro SO and Ozoje MO, 2017. Reproductive performance, feed intake and efficiency of indigenous and crossbred turkeys. Journal of Agricultural Science and Environment 18: 47-58.

Iqbal J, Mukhtar N, Rehman ZU, Khan SH, Ahmad T, Anjum MS, Pasha RH and Umar S, 2017. Effects of egg weight on the egg quality, chick quality, and broiler performance at the later stages of productive (week 60) in broiler breeders. Journal of Applied Poultry Research 26: 183-191. https://doi.org/10.3382/japr/pwf061

Luiting P and Urff EM, 1991. Residual feed consumption in laying hens. 2. Genetic variation and correlations. Poultry Science 70: 1663-1672. https://doi.org/10.3382/ps.0701663

Manyelo TG, Selaledi L, Hassan ZM and Mabelebele M, 2020. Local chicken breeds of Africa: Their description, use and conservation methods. Animals 10: 2257. https://doi.org/ $\underline{10.3390 / \text { ani10/22257 }}$

Nestor KE, McCartney MG and Harvey WR, 1967. Genetics of growth and reproduction in the turkey. 1. Genetic and nongenetic variation in body weight and body measurements. Poultry Science 46: 1374-1384. https://doi.org/10.3382/ ps.0461374

Ngu GTR, Butswat IS, Mah GD and Ngantu HN, 2014. Characterization of small-scale backyard (Melleagris gallopavo) production system in Bauchi State-Nigeria and its role in poverty alleviation. Livestock Research for Rural Development 26: 1 .

Ogah DM, 2011. Assessing size and conformation of the body of Nigerian indigenous turkey. Slvak Journal of Animal Science 44: 21-27.

Padhr MK, 2016. Importance of indigenous breeds of chicken for rural economy and their improvement for higher production performance. Scientifica 2016: 2604685. https://doi.org/ $10.1155 / 2016 / 2604685$

Perez-Lara E, Camacho-Escobar MA, Avila-Serrano NY, Arroyo-Ledezma J, Sanchez-Bernal EI, Torre MR and Reyes-Borques V, 2013. Productive evaluation of slow growing Mexican turkeys with different diets in confinement. Open Journal of Animal Sciences 3: 46-53, https://doi.org/10.4236/ojas.2013.31007

Tullett SG and Burton FG, 1982. Factors affecting the weight and water status of the chick at hatch. British Poultry Science 23: 361-369. https://doi.org/10.1080/0007/688208447969

Udoh UH, Nwaogwugwu UC and Esiet ES, 2012. Egg Laying Characteristics of three (naked neck, normal feathered and fizzled feather) Nigerian local chickens. Journal of Agriculture, Biotechnology and Ecology 5: 3-99.

Visscher PM, Hill WG and Wray NR, 2008. Heritability in the genomics era-concepts and misconceptions. Natures Reviews Genetics 9: 255-266. https://doi.org/10.1038/nrg2322

Yakubu A, Abimiku K, Musa Azara IS, Idahor KO and Akinsola OM, 2013. Assessment of flock structure, preference in selection and traits of economic importance of domestic turkey (Meleagris gallopavo) genetic resources in Nasarawa state, Nigeria. Livestock Research for Rural Development 25: 18 . 